\title{
Spot on! Zelfredzaamheid en verwachtingen van burgers bij een black-out
}

\author{
Evelien De Pauw, Arne Dormaels \& Marleen Easton
}

Sinds 2014 baren de winterperiodes de Belgische federale overheid zorgen wat de elektriciteitsbevoorrading betreft. De Belgische elektriciteitsproductie kan op heden de vraag op piekmomenten niet bijhouden en wordt gedwongen om stroom te importeren uit naburige landen. Binnen deze gegeven context laaide de discussies hoog op en doken tevens allerhande doemscenario's van mogelijke lange black-outs op. De gevolgen van een stroomonderbreking zijn immers niet beperkt tot het niet beschikken over verlichting. De maatschappelijke impact is zeer breed of diepgaand. $\mathrm{Na}$ verloop van tijd vallen ook andere energiebronnen uit, het openbare leven valt lam, het internet is niet meer beschikbaar, ... Ook de economische schade valt allicht niet te overzien.

Deze studie polste naar de zelfredzaamheid en verwachtingen van de burger bij een mogelijke black-out. In twee Belgische centrumsteden werden aan de hand van een kwantitatieve methode 473 burgers bevraagd. Er werd gekeken naar hun eigen aandeel in oplossingen. Waar vindt men hulp en informatie en in welke mate dient de overheid hier in te voorzien? Verder bestudeert dit artikel de verhouding tussen burger en overheid. Verwachten burgers in dergelijke noodsituaties een sturende overheid met een stok achter de deur of hebben zij eerder nood aan een overheid die openstaat voor inspraak?

\section{Context}

De kracht van de samenleving werd vorige decennia hoofdzakelijk gemeten aan de hand van economische cijfers. Hoe groter de economische groei, hoe beter de welvaart en de kwaliteit van samenleven. Na de aanslagen van 9/11 zien we een verschuiving en worden veiligheid en veiligheidszorg meer en meer gezien als indicatoren om de kwaliteit van de samenleving te meten. Veiligheid wordt een cruciale variabele in de wijze waarop burgers en bedrijven de kwaliteit van de samenleving beoordelen (Muller 2004).

De kwaliteit van de samenleving en de veiligheid wordt dan ook in eerste instantie toegeschreven aan een samenleving zonder criminaliteit en potentiële terroristische dreigingen (Petermann e.a. 2011). Daarbovenop tonen ook natuurlijke rampen de kwetsbaarheid van onze samenleving aan. Overstromingen, aardbevingen, vulkaanuitbarstingen zijn ons de laatste jaren niet vreemd. Ook crisissituaties ontstaan vanuit een technisch falen, zorgden in het verleden voor chaos. De gasexplosie in Gellingen (2001) en de treinramp in Wetteren (2013) zijn hiervan voorbeelden. 
Tot slot is onze samenleving vandaag de dag heel afhankelijk geworden van technologie en kritische infrastructuren om verder te kunnen functioneren. Zo lang alles functioneert, verkeren we in een veilige situatie, maar we worden heel kwetsbaar als we daar geen beroep meer op kunnen doen.

De Europese Richtlijn 2008/114/EG inzake de identificatie van Europese kritieke infrastructuren definieert het concept 'kritieke infrastructuur' als volgt:

'een voorziening, systeem of een deel daarvan op het grondgebied van de lidstaten dat van essentieel belang is voor het behoud van vitale maatschappelijke functies, de gezondheid, de veiligheid, de beveiliging, de economische welvaart of het maatschappelijk welzijn, waarvan de verstoring of vernietiging in een lidstaat aanzienlijke gevolgen zou hebben doordat die functies ontregeld zouden geraken' (Dupont \& Reiniers 2010).

Kritische infrastructuren die een belangrijke rol spelen in onze samenleving, waar de bevolking constant op aangewezen is en die bovendien een belangrijke rol spelen in verder 'draaien' van de economie en de samenleving zijn: energie, water, voedselvoorziening, transport en vervoer, informatietechnologie \& telecommunicatie, bank- en verzekeringswezen, autoriteiten en administratie en de gezondheidssector (Lens 2009).

De katalysator voor een mogelijke grote nationale ramp ligt in een stroomuitval. De gevolgen van een stroomonderbreking zijn immers niet beperkt tot het niet beschikken over verlichting. De maatschappelijke impact is zeer breed of diepgaand. Na verloop van tijd vallen ook andere energiebronnen uit, het openbare leven valt lam, het internet is niet meer beschikbaar, ... Met andere woorden, alle andere kritische infrastructuren zijn afhankelijk van energietoevoer. Een langdurige black-out is bijgevolg een grootschalige verstoring van het openbare leven, een economische ramp en een aanzienlijke bedreiging voor de openbare veiligheid (Petermann e.a. 2011).

Ook de Belgische overheid is zich bewust van deze situatie. Sinds 2014 baren de winterperiodes de federale overheid zorgen wat de elektriciteitsbevoorrading betreft. De Belgische elektriciteitsproductie kan op heden de vraag op piekmomenten niet bijhouden en wordt gedwongen om stroom te importeren uit naburige landen. Bijkomend is de Belgische productie voor $55 \%$ afhankelijk van nucleaire productie. Door het uitvallen van de kernreactoren Tihange 2 en Doel 3 dreigt de import alleen niet te volstaan om het tekort op te vangen. Hoewel het ministerieel besluit van 3 juni 2005 tot vaststelling van het afschakelplan van het transmissienet van elektriciteit, kortweg 'afschakelplan', al tien jaar bestaat, werd het pas in de winter van 2014 actueel. Elia, beheerder van het Belgische transmissienet voor elektriciteit, bedacht een globaal afschakelplan dat automatisch kan worden geactiveerd in geval van een incident op het hoogspanningsnetwerk of manueel in geval van schaarste. Zo'n afschakelprocedure (rolling-out) heeft als doel het evenwicht van het netwerk in stand te houden, om een algemene blackout van de elektriciteitsbevoorrading van het land te vermijden. Anno 2015 werd dit afschakelplan nog verder uitgebreid. In 2014 waren er zes schijven die elk om beurt konden afgeschakeld worden, in het nieuwe plan zijn het er acht. Wel is het 
zo dat de laatste schijf (schijf 1) enkel gebruikt wordt bij 'automatische' afschakeling (dus bij een incident) en niet manueel wordt afgeschakeld wanneer er een tekort dreigt. Nieuw is ook dat provinciehoofdplaatsen, stadscentra van gemeenten met meer dan 50.000 inwoners en commerciële luchthavens of havens niet afgeschakeld worden (De Standaard 16 september 2015).

Binnen deze gegeven context laaide vorig jaar de discussies hoog op en doken tevens allerhande doemscenario's van mogelijke lange black-outs op. In verschillende gemeenten zorgde het afgekondigde afschakelplan voor grote politieke discussies (zie o.a. afschakelplan veroorzaakt politieke rel, De Standaard 18 september, 2014; Gentse haven bedreigd, De Morgen 19 september 2014). Ook de federale overheid zat niet stil en lanceerde de campagne 'ONOF'. Deze website informeerde de burgers over het afschakelplan en sensibiliseerde tot het verstandig omgaan met energie in de wintermaanden.

Deze gegeven context was meteen het voorwerp van voorliggend onderzoek. Indien een black-out kan leiden tot een nationale ramp, is het met andere woorden noodzakelijk dat we hierop voorbereid zijn. Deze studie polste naar de zelfredzaamheid en verwachtingen van de burger bij een mogelijke black-out. Er werd in eerste instantie gekeken naar de zelfredzaamheid van burgers en hun eigen aandeel in oplossingen. Waar vindt men hulp en informatie en in welke mate dient de overheid hierin te voorzien? Verder bestudeert dit artikel de verhouding tussen burger en overheid. Verwachten burgers in dergelijke noodsituaties een sturende overheid met een stok achter de deur of hebben zij eerder nood aan een overheid die openstaat voor inspraak?

Dit artikel zal in paragraaf 2 de begrippen verder operationaliseren. Wat verstaan we onder zelfredzaamheid en welke rol speelt een overheid hierin? Paragraaf 3 omschrijft de methodologie. Daarna volgt een beschrijving van de resultaten (par. 4) en staan we stil bij de lessen die de overheid hieruit kan trekken (par. 5).

\section{Begrippenkader}

Alvorens te gaan bekijken hoe zelfredzaam burgers zijn en wat hun verwachtingen zijn, is het essentieel te kaderen wat we onder deze begrippen verstaan.

Self-efficacy of zelfredzaamheid is de notie dat 'een individu verwacht dat hij in staat is adequaat om te kunnen gaan met risico's' (Bandura 2000). Met andere woorden, het gaat om het zelf in staat zijn om in zijn basisbehoeften te voorzien, zonder hulp van anderen. Dit is ook de omschrijving die we terugvinden in Van Dale, zelfredzaamheid staat voor het 'vermogen (van ouderen, zieken of gehandicapten) om te leven zonder professionele hulpverlening'. Zelfredzaamheid is in deze betekenis tevens een doel, namelijk het zelfstandig en autonoom kunnen oplossen van levensproblemen. Mensen willen het zonder organisaties en professionals redden. Zelfredzaamheid krijgt vanuit deze betekenis een emancipatoire bijklank.

Wanneer we dit verder toepassen op crisissituaties, komen we in de Nederlandse literatuur vaak terug op de publicaties van het Crisislab. Ruitenberg en Helsloot (2004: 4) omschrijven zelfredzaamheid in tijden van crisis als: 
'alle handelingen die door burgers verricht worden ter voorbereiding op, tijdens en na rampen en zware ongevallen om zichzelf en anderen te helpen en de gevolgen van de ramp of het zware ongeval te beperken'.

Neuvel, Groenendaal en De Boer (2010: 9) zien zelfredzaamheid als:

'het vermogen van burgers om zichzelf en anderen te helpen in voorbereiding op, tijdens en na crises. Waar nodig en mogelijk ondersteund door de overheid'.

In deze laatste definitie zien we meteen het emancipatorische denken terug. De overheid ondersteunt waar nodig de burgers om in hun zelfredzaamheid te voorzien. Volgens Ruitenberg en Helsloot (2004) kan er bij zelfredzaamheid onderscheid worden gemaakt in drie fases. Dit is de zelfredzaamheid van de burger voorafgaand aan een incident, tijdens een incident en na een incident. Deze studie richt zich enkel op de zelfredzaamheid voorafgaand aan het incident en de inschatting die burgers maken van de zelfredzaamheid tijdens het incident. Het onderzoek richt zich dus niet op de afhandeling tijdens en na het incident, gewoonweg omdat er geen incident was. Hierdoor onderscheidt deze studie zich van voorafgaande Nederlandse onderzoeken die onder andere de zelfredzaamheid van burgers bestuderen tijdens de stroomonderbreking in de Bollenstreek (Neuvel e.a. 2010) en de stroomuitval in de Bommeler- en Tielerwaard (Scholtens \& Helsloot 2007).

Verder vinden we in de literatuur een aantal indicatoren terug die van invloed kunnen zijn op de zelfredzaamheid van burgers. De mate waarin iemand zelfredzaam is in de voorbereiding op een incident hangt volgens Terpstra (2010) af van drie indicatoren:

- de perceptie van het risico en het incident;

- de perceptie van de eigen verantwoordelijkheid;

- de perceptie van de mogelijke voorbereidingsmaatregelen.

Naast deze individuele kenmerken blijkt ook de invloed van de omgeving, namelijk de betrokkenheid en het vertrouwen in de buurt, een rol te spelen (Wijnja 2014).

Wat de eerste indicator betreft toont onderzoek aan dat mensen zich niet echt goed voorbereiden op een mogelijke ramp wanneer men ervan overtuigd is dat de kans op een mogelijke crisis laag is of als zij geen voldoende inschatting kunnen maken van de situatie. Het denken over een mogelijke 'voorbereiding' ligt bij het moment dat de rampdreiging als 'echt' wordt ervaren: 'Unless the warning recipient believes that the threat is genuine, he is not likely to undertake any protective action' (Perry 1985: 70).

In het kader van dit onderzoek werd met andere woorden de berichtgeving over een mogelijke black-out als trigger aanzien. We vertrekken vanuit de hypothese dat mensen zich 'beter' of 'meer' zouden gaan voorbereiden op een mogelijke stroomonderbreking. Contradictorisch laat ander onderzoek zien dat de voorbereiding door burgers op kleinekansrisico's door overheidsinitiatieven nauwelijks 
te bevorderen is (Ruitenberg \& Helsloot 2004: 106). Met andere woorden, de berichtgeving door de overheid en de campagnes ONOFF zouden geen effect hebben. Wij vertrekken echter vanuit de hypothese dat de bewustmaking door de overheid een zeker effect heeft gehad op de perceptie van burgers en dat zij zich hierdoor effectief meer hebben voorbereid op een stroomonderbreking.

De tweede indicator, de perceptie van de eigen verantwoordelijkheid, gaat uit van de veronderstelling dat burgers zich meer gaan voorbereiden als ze van mening zijn dat ze zelf verantwoordelijk zijn voor het voorzien in hun eigen 'veiligheid' (Terpstra 2010). Met andere woorden, als burgers het gevoel hebben dat de overheid een rol speelt in het nemen van initiatieven in kader van een mogelijke stroomonderbreking, zullen deze burgers ook hogere verwachtingen hebben van diezelfde overheid. Naarmate ze de eigen verantwoordelijkheden lager achten, zullen zij zich ook minder voorbereiden (Helsloot \& Van 't Padje 2010).

Hijlkema, Van der Meulen en Moll (2011: 7) gingen na in hoeverre burgers zelf vinden een taak te hebben in de verschillende fases van de veiligheidsketen. Wat betreft de voorbereiding op een risico voor zichzelf en voor buurtbewoners was $34 \%$ tot $73 \%$ van de respondenten van mening dat de hulpdiensten en overheid in alle fases van een noodsituatie een rol hebben te vervullen. De meeste respondenten (62\%) geven ook aan zelf een verantwoordelijkheid te hebben bij het voorkomen van en voorbereid zijn op een ongeval, ramp of crisis (Hijlkema, Van der Meulen \& Moll 2011: 12). Dit laatste staat meteen in verband met de derde indicator, namelijk de perceptie van de mogelijke voorbereidingsmaatregelen. Hierbij gaat het om de perceptie dat de maatregelen daadwerkelijk effectief zijn om de veiligheid van jezelf of anderen te vergroten. Mensen zullen zich dus eerder inzetten wanneer men ervan overtuigd is dat men daadwerkelijk iets kan doen om de veiligheid van zichzelf of anderen te garanderen (Terpstra 2010: 15). Met andere woorden, men zal eerder een beroep doen op de overheid of anderen als men denkt zelf niets 'zinnigs' te kunnen bijdragen.

In onderhavig onderzoek werd dan ook gepolst, rekening houdende met deze laatste twee indicatoren, naar de verwachtingen van de burgers ten opzichte van de overheid. Hierbij vertrekken we vanuit de hypothese dat men vooral zaken van de overheid zal verwachten waarin men denkt niet zelf te kunnen voorzien.

Tijdens het incident wordt vaak gesproken over slachtoffers, een term dat impliceert dat getroffenen passief en afhankelijk zijn, terwijl voor veel getroffenen vaak het tegendeel geldt. Naast de idee dat burgers apathisch reageren in geval van een ramp, bestaan ook nog de veronderstellingen dat burgers standaard in paniek raken bij een ramp of zouden gaan plunderen (Helsloot 2015). De 3-p mythes (passiviteit, paniek en plundering) zijn dan ook niet gebaseerd op fundamenteel wetenschappelijk onderzoek. Integendeel, bepaalde studies laten zien dat burgers ook een waardevolle uitbreiding van de hulpverleningscapaciteit kunnen zijn en dat zij vaak anders reageren dan op basis van hiervoor genoemde vooronderstellingen (mythen) verwacht zou mogen worden (Bankhoff, Frerks \& Hilhorst 2004; Ruitenberg \& Helsloot 2004). Helsloot gaat zelfs nog een stap verder en geeft aan dat het vaak de professionals en de overheid zijn die problemen hebben met georganiseerde burgers en dat zij liever passiviteit zouden hebben (Helsloot 2015). 
Resultaten van verschillende Europese studies tonen aan dat burgers vaak in eerste instantie zelf willen instaan voor hun probleemoplossing. Het organiseren van hulp hoeft voor hen niet altijd te worden opgevangen door professionelen (Petermann e.a. 2011; Swcheer e.a. 2014; Neuvel, Groendendaal \& Den Boer 2010).

Rekening houdend met deze definitie van zelfredzaamheid focussen wij ons voor dit onderzoek op alle handelingen die burgers zelf nemen ter voorbereiding van een crisis, in dit geval een mogelijke stroomonderbreking, en onderzochten we de link met de drie indicatoren die de voorbereiding van een incident in kaart brengen. Voorts hadden we ook aandacht voor de verwachtingen en handelingen van burgers tijdens het incident. Dit bracht ons tot de volgende onderzoeksvragen.

- In welke mate zijn de respondenten voorbereid op een mogelijke black-out?

- In welke mate neemt men zelf initiatief?

- In welke mate is men bereid anderen te helpen?

- Wat verwacht men van de overheid?

Hieraan gekoppeld kijken we naar de relatie die de burger heeft met z'n buurt en hoeveel vertrouwen de burger heeft in de overheid, vanuit de hypothese dat mensen die zich 'veilig' voelen in hun buurt, meer bereid zullen zijn de anderen te helpen en dat mensen die meer vertrouwen hebben in de overheid zich minder zullen voorbereiden.

\section{Methodologie}

In twee Belgische centrumsteden ${ }^{1}$ waar het afschakelplan van kracht is, werden aan de hand van een kwantitatieve methode 473 burgers bevraagd. De keuze van de centrumsteden zelf was louter toevallig. De enige voorwaarde waaraan diende te worden voldaan, was dus de aanwezigheid van het afschakelplan.

De studenten Bachelor Maatschappelijke Veiligheid van de Vives Hogeschool, Kortrijk, trokken in het kader van het vak Technologie en Infrastructuur de stad Kortrijk in. De studenten van de master in Bestuurskunde en Publiek Management van de UGent namen in het kader van het vak seminarie beleidsdomein veiligheid, Gent voor hun rekening. Met een gestandaardiseerde vragenlijst polsten zij naar de zelfredzaamheid en verwachtingen van mensen.

De steekproeftrekking gebeurde enerzijds trapsgewijs, met andere woorden de selectie van de straten die werden opgenomen in deze studie werden op voorhand bepaald. Gezien de actualiteit van het thema en het feit dat mensen zich reeds bewust waren van een mogelijke rolling-out, werden straten geselecteerd die voorwerp zijn van een mogelijke afschakeling.

Om de respons te verhogen werd gekozen om de vragenlijsten zelf met de respondenten te overlopen en niet over te gaan tot het bussen van de vragenlijst. Elke

1 Een centrumstad wordt in Vlaanderen omschreven als een stad die een centrale functie uitoefent voor zijn omgeving, onder andere op het vlak van werkgelegenheid, verzorging, onderwijs, cultuur en ontspanning. Het Vlaamse Gewest erkent dertien centrumsteden. Zij krijgen deze naam niet op basis van inwonersaantallen, maar op basis van uitrustingsniveau. 
student kreeg de opdracht tien enquêtes af te nemen op willekeurige basis binnen een van de geselecteerde straten.

Ter controle werd aan de studenten gevraagd om contactgegevens van de respondenten neer te schrijven - we beloofden wel anonieme verwerking - met de mogelijkheid dat de docenten steekproefsgewijs de mensen konden contacteren met de vraag of de vragenlijst wel effectief werd afgenomen. Op deze manier trachtten we wat meer betrouwbaarheid in te bouwen.

De vragenlijst zelf werd gebaseerd op een eerdere studie 'Relief Needs and Willingness to Help in the Event of Long-term Power Blackout, Results of a citizen survey in three Berlin Districts' (Ohder, Ropke, Sticher e.a. 2014) en omvatte zeven categorieën van vragen.

Een eerste categorie van vragen polste naar de persoonlijke woonomstandigheden van de respondenten. Deze details, zoals het aantal jaren dat men in een buurt woont, tonen aan hoe vertrouwd men is met een buurt en kan van invloed zijn op de bereidheid tot helpen van anderen (zie ook supra: het vertrouwen in de buurt is van invloed op medewerking tijdens ramp). Een tweede categorie vragen polst naar de eigen voorzieningen, zoals voedsel, medicijnen, vervoer, communicatiemiddelen. Deze zaken kunnen van belang zijn gedurende een langdurige stroomonderbreking. Een derde categorie bevraagt de verwachte hulp en informatie tijdens een stroomuitval. Het vierde thema dat werd aangesneden, is de vraag of men bereid is anderen te helpen. Tot slot werd een aantal vragen gesteld over de buurt en het vertrouwen in de overheid, om te eindigen met een aantal persoonskenmerken.

De steekproef (zie bijlage 1 ) is gelijk verdeeld naar geslacht. 48,9\% van de respondenten is man en $50,8 \%$ van de respondenten is van het vrouwelijk geslacht. De meeste respondenten zijn afkomstig van Gent: 70,3\%. 29,7\% van de respondenten woont in Kortrijk. De leeftijdsgroep 19-30 is het meest vertegenwoordigd met $27,5 \%$. Dit is opvallend en kan worden verklaard doordat de steekproef in twee studentensteden tot stand kwam. De leeftijdsgroepen 31-40, 41-50 en 51-60 zijn ongeveer gelijk vertegenwoordigd in de steekproef met respectievelijk 16,1, 15,9 en $16,9 \%$ van de respondenten. 11,4\% van de respondenten was tussen de 61 en 70 jaar oud. 11,9\% van de respondenten was ouder dan 70 jaar. 89,6\% van de respondenten heeft geen immigratieachtergrond; beide ouders zijn van Belgische afkomst. Ongeveer de helft van de respondenten heeft een betaalde job: 43,9\% werkt voltijds en $11,7 \%$ werkt deeltijds. $19,7 \%$ van de respondenten studeert. Een kleine minderheid van $3,6 \%$ van de respondenten is werkloos, $17,6 \%$ is gepensioneerd en $2,1 \%$ is huisvrouw of -man.

Ongeveer een op de vijf respondenten woont alleen: 22,7\%. Een duidelijke meerderheid van $64,9 \%$ woont samen, waarvan $31,7 \%$ met schoolgaande kinderen en $12,5 \%$ met peuters.

Opvallend is dat $28,5 \%$ van de respondenten aangeeft zelf afhankelijk te zijn van geneesmiddelen. Verder heeft 7,8\% minstens eenmaal per week medische verzorging nodig en is $2,7 \%$ van de respondenten afhankelijk van medische apparaten. $6,6 \%$ heeft een beperkte mobiliteit. Wat de persoon betreft met wie men samenleeft, is $19,5 \%$ afhankelijk van geneesmiddelen en heeft 5,8\% minstens eenmaal 
per week medische zorgen nodig. De ondersteuning van medische apparaten is $2,8 \%$ en $4,5 \%$ van de respondenten heeft een beperkte mobiliteit.

\section{Bevindingen}

Graag zoomen we in op een tweetal topics, namelijk de zelfredzaamheid en de verwachtingen van burgers in het geval van een stroomonderbreking. Uit de literatuur blijkt dat burgers zich vaak niet bewust zijn van het feit dat bij een langdurige stroomonderbreking hun vermogen om hun normale levenscondities te controleren, afneemt. Zelden staan burgers stil bij het feit hoe afhankelijk wij zijn van elektriciteitsvoorzieningen (Petermann e.a. 2011). Het feit dat in België de mogelijke rolling-outs werden aangekondigd, doet ons vermoeden dat de burger zich enigszins wel gaat organiseren (zie supra).

Om de zelfredzaamheid van de burger te meten en het collectief vermogen om zichzelf en anderen te helpen tijdens een mogelijke stroomuitval in kaart te brengen, werd onder andere gevraagd naar de voorraad etenswaren, drank en geneesmiddelen waar burgers over beschikken, en de bereidheid om anderen te helpen.

\subsection{Voorzorgsmaatregelen}

Uit buitenlandse studies blijkt dat de burger weinig is voorbereid op een stroomuitval die meerdere dagen duurt. Een Zwitserse studie die een bevolkingsbevraging bij de inwoners van de stad Zürich betrof, toont aan dat een mogelijke stroomonderbreking voor de meeste inwoners geen issue is. Burgers zien dit niet als een mogelijke bedreiging, vandaar dat zij ook geen al te grote voorzorgen nemen (Stiftung Risiko-Dialog 2007, in: Petermann e.a. 2011). Ook andere studies bevestigen dit; indien men het risico als laag inschat, neemt men minder voorzorgen (Helsloot \& Van 't Padje 2010). De resultaten van het huidige onderzoek sluiten aan bij deze trend.

Uit de resultaten (tabel 3) blijkt dat de bevraagde respondenten globaal gezien over voldoende etenswaren beschikken die koud gegeten kunnen worden. 74,5\% (348) van de respondenten geeft aan over voldoende etenswaren te beschikken om een periode van minstens drie tot vier dagen te overbruggen. De resultaten voor de drankvoorraad zijn beduidend hoger: 94,4\% (440) van de respondenten heeft voldoende drank in huis voor een periode van minstens drie dagen. 53,9\% (251) beschikt zelfs over voldoende drank om meer dan zes dagen te voorzien in hun behoeften. $78,2 \%$ (276) van de respondenten heeft medicatie om zichzelf te helpen ingeval zich een stroomuitval voordoet die langer dan zes dagen zou duren.

Hoewel deze globale resultaten doen vermoeden dat de burger voldoende tot goed is voorbereid om meerdere dagen te voorzien in zijn of haar basisbehoeften, bekomen we interessante verschillen op basis van gezinssamenstelling en specifieke behoeften. Vanuit een rationele logica kan worden verwacht dat gezinnen met peuters, ouderen, minder mobiele gezinnen of gezinnen die afhankelijk zijn van 
Tabel 1 Voorzieningen in het huishouden (in \%, tussen haakjes absolute aantallen)

\begin{tabular}{|c|c|c|c|}
\hline \multicolumn{4}{|c|}{ Etenswaren die koud gegeten kunnen worden (brood, conserven, fruit, enz.) } \\
\hline ...I-2 dagen & ...3-4 dagen & ...5-6 dagen & ...meer dan 6 dagen \\
\hline $25,5(119)$ & $41,8(195)$ & I5,8 (74) & $16,9(79)$ \\
\hline \multicolumn{4}{|c|}{ Drank (mineraal water, sappen, enz.) } \\
\hline ...I-2 dagen & ...3-4 dagen & ...5-6 dagen & ... meer dan 6 dager \\
\hline $5,6(26)$ & I5,2 (7I) & $25,3(118)$ & $53,9(25 I)$ \\
\hline \multicolumn{4}{|c|}{ Belangrijke geneesmiddelen (indien nodig) } \\
\hline ...I-2 dagen & ...3-4 dagen & ...5-6 dagen & ... meer dan 6 dager \\
\hline 6,5 (23) & $8,2(29)$ & $7,1(25)$ & $78,2(276)$ \\
\hline
\end{tabular}

belangrijke medische hulp beter zijn voorzien op een mogelijke stroomuitval. De resultaten tonen alvast een ander beeld (zie tabellen in bijlage 2).

\subsubsection{Gezinnen met peuters kwetsbaar voor voeding}

Gezinnen met kinderen beschikken voor meerdere dagen over voedsel in vergelijking met gezinnen zonder kinderen (zie tabel 4). Een opvallende vaststelling is dat gezinnen met één of meer peuters significant minder zijn voorzien van voeding en drank voor meerdere dagen (zie tabel 5). Ook in absolute cijfers stellen we vast dat gezinnen met schoolgaande jongeren en gezinnen zonder kinderen vaker aangeven dat zij voor meerdere dagen over voedsel beschikken. 37,1\% van de gezinnen met schoolgaande kinderen geeft aan dat zij over voedsel beschikken voor vijf of meer dagen (zie tabel 6). Alleenstaanden (33,8\%), koppels zonder kinderen $(32,3 \%)$ en gezinnen met peuters $(32,2 \%)$ beschikken in mindere mate in rantsoen voor vijf of meer dagen.

\subsubsection{Respondenten met slechte mobiliteit voorzien in voldoende drank}

$87,1 \%$ van de gezinnen met iemand met een slechte mobiliteit zijn voorzien van drank voor minstens vijf dagen. Alleenstaanden (80,7\%), koppels $(78,4 \%)$ en gezinnen met schoolgaande kinderen $(81,2 \%)$ scoren beduidend lager. In dit rijtje is de meest opvallende score voor gezinnen met peuters. Slechts $77,9 \%$ van de gezinnen met peuters kan meer dan vijf dagen rondkomen met water en frisdrank.

\subsubsection{Gezinnen met peuters kwetsbaarder voor medicatie dan hulpbehoevenden}

De meest opvallende verschillen stellen we vast met betrekking tot voldoende voorzieningen in het huishouden voor dringende geneesmiddelen. Een logisch uitkomst is dat $91,7 \%$ van de respondenten die afhankelijk zijn van dringende geneesmiddelen langer dan vijf dagen voort kunnen. Gezinnen met kinderen (86,8\%), alleenstaanden $(85,5 \%)$ en samenwonenden zonder kinderen $(85,1 \%)$ beschikken duidelijk voor een langere periode in voldoende belangrijke geneesmiddelen. Opmerkelijk resultaat is dat personen die moeilijk mobiel zijn duidelijk in mindere mate zijn voorzien: $82,8 \%$. Het meest opmerkelijke verschil stellen we 
van wie verwacht men hulp?

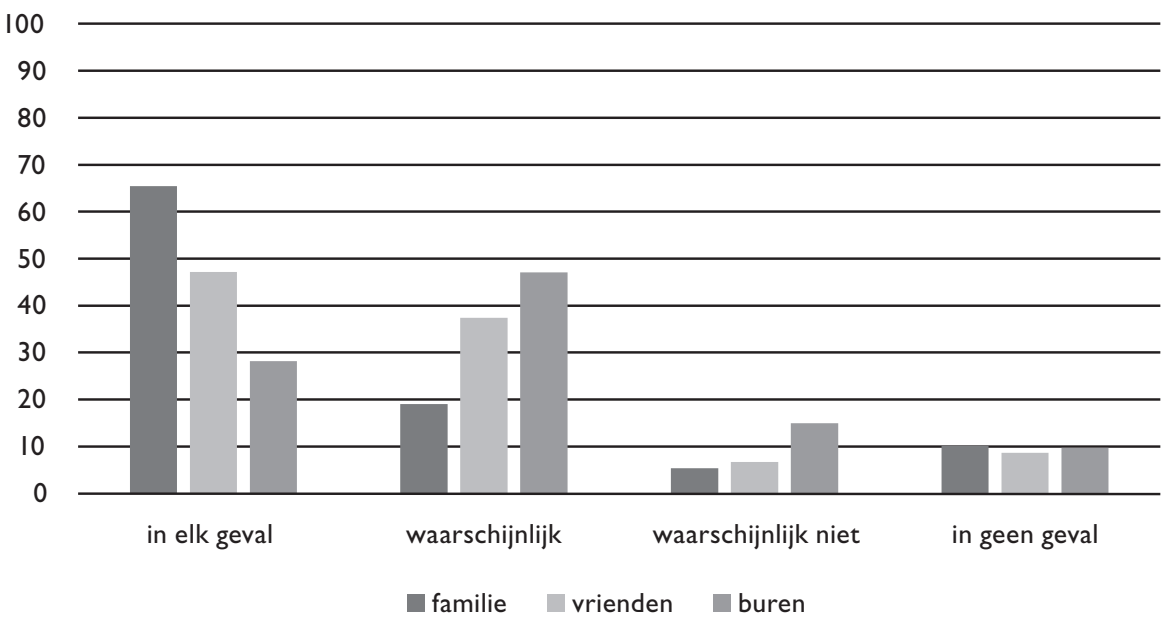

Figuur $1 \quad$ Van wie wordt hulp verwacht?

vast met gezinnen met peuters. Slechts $68,9 \%$ van de gezinnen met peuters geeft aan meer dan vijf dagen in medicatie te kunnen voorzien.

Wat we helaas niet uit deze resultaten kunnen halen, is een antwoord op de vraag of deze voorzieningen eerder toevallige voorbereidingen waren of specifiek genomen waren naar aanleiding van de aankondiging van het afschakelplan. Wel kunnen we concluderen dat mensen min of meer georganiseerd zijn en over voldoende rantsoen beschikken; enkel gezinnen met kinderen en vooral peuters vormen hier een 'risicogroep'. De hulpbehoevendheid in geval van een langdurige stroomuitval is met andere woorden niet gelijk verdeeld over de verschillende gezins- en woonomstandigheden.

\subsection{Van wie wordt hulp verwacht?}

In geval van een stroomonderbreking verwachten respondenten in de eerste plaats hulp van familieleden $(65,4 \%, 303)$. Op de tweede plaats verwacht men hulp van vrienden en kennissen $(47,2 \%, 218)$. Opvallend is dat er duidelijk minder hulp wordt verwacht van de buren: slechts 47,2\% (218) van de respondenten geeft aan dat zij zeer zeker op hulp kunnen rekenen van buren. Een belangrijk aandachtspunt bij deze resultaten is dat 59\% (279) van de respondenten aangeeft dat zij hun familie niet te voet kunnen bereiken in geval van problemen. Vrienden en kennissen zijn gemakkelijker bereikbaar: 62,9\% (296) geeft aan dat vrienden te voet kunnen worden bereikt.

Het feit dat familie of vrienden de eerste aanspreekbron zijn, kan ook deels worden verklaard vanuit de psychologie van de mens zelf. Een gevoel van hulpeloosheid wordt intrinsiek niet altijd aanvaard. Het 'toegeven' dat men in nood is, doet men liever bij dichte familie, vrienden, en minder bij kennissen (De Pauw \& De Prins 2013). 


\section{Tabel 2 Bereidheid om te helpen}

\begin{tabular}{llll}
\hline $\begin{array}{l}\text { bereid om mensen te } \\
\text { helpen die in mijn } \\
\text { directe buurt wonen }\end{array}$ & $\begin{array}{l}\text { bereid om mensen te } \\
\text { helpen die in mijn } \\
\text { buurt wonen }\end{array}$ & $\begin{array}{l}\text { bereid om mensen te } \\
\text { helpen die in andere } \\
\text { wijken van Gent } \\
\text { wonen }\end{array}$ \\
$\begin{array}{l}\text { schaal_veiligheid buurt } \\
\text { sig. (2-tailed) }\end{array}$ & $.117^{*}$ & $.18 I^{* *}$ & $.227^{* *}$
\end{tabular}

$\mathrm{p}=*$ correlatie is significant op .05 niveau $<* *$ correlatie is significant op .01 niveau

\subsection{Bereidheid om anderen te helpen}

Een duidelijke meerderheid van de respondenten geeft aan dat zij bereid zijn om hun nabije buren bij te staan in geval van een stroomuitval. $58,1 \%$ is zeer zeker dat nabije buren op hulp kunnen rekenen. Deze bereidheid is in mindere mate aanwezig op buurtniveau. Slechts $35,2 \%$ van de respondenten (164) is bereid om andere bewoners in de buurt te helpen. Andere bewoners in de stad kunnen op minder solidariteit beroep doen. 10,1\% van de respondenten is bereid om heel zeker andere stadsbewoners die niet afkomstig zijn uit de buurt te helpen.

Wat hierbij opvalt, is dat naarmate respondenten zich minder veilig voelen in hun buurt, zij in mindere mate bereid zijn om hulp te bieden. ${ }^{2}$ De Spearman's rho-test duidt op een statistisch significant verband tussen het veiligheidsgevoel in de buurt en de bereidheid om hulp te bieden. Deze relatie is het meest uitgesproken voor de bereidheid om mensen helpen die in andere wijken wonen (rs[451] $=.227, p<.001)$ en minder voor buurtbewoners $(r s[461]=.181, p<.001)$ en de naaste buren $(r s[464]=.117, p<.05)$. De relatie is echter beperkt, wat doet vermoeden dat de bereidheid om te helpen niet zozeer wordt beperkt door het eigen veiligheidsgevoel. Naast de kenmerken van de buurt blijken individuele kenmerken, zoals leeftijd en tewerkstelling, geen significante invloed te hebben op de bereidheid om anderen te helpen. Dit doet vermoeden dat er een belangrijk maatschappelijk draagvlak bestaat om burgers aan te spreken op hun zelfredzaamheid en hun bereidheid om buurtbewoners te helpen tijdens een langdurige stroomuitval. Deze inzichten sluiten aan bij de inzichten van Ruitenberg en Helsloot (2004), Petermann (2011) en Neuvel, Groenendaal en Den Boer (2010), waarbij werd aangetoond dat burgers zichzelf organiseren.

Deze resultaten tonen een zekere mate van solidariteit aan. Ook al verwacht de burger in eerste instantie geen hulp van zijn buren, toch geeft de helft aan hulp te willen bieden. Met andere woorden, wanneer mensen door omstandigheden (niet

2 Voor de schaalscore 'veiligheid in de buurt' werden de antwoorden op de stellingen 'je je onveilig voelt in jouw buurt?', 'je bepaalde plekken in jouw buurt mijdt omdat je je onveilig voelt?', 'je de deur niet open doet voor onbekenden omdat je je onveilig voelt?' en 'je wel eens vermijdt om bij duisternis weg te gaan van huis?' gehercodeerd: Nooit $=0$, Zelden $=1$, Soms $=2$, Dikwijls $=3$, Altijd $=4$. Een hoge schaalscore impliceert een sterk onveiligheidsgevoel in de buurt. Een lage schaalscore impliceert een veilig gevoel in de buurt. Deze schaal is intern consistent: Cronbach's Alpha $=.839$. 


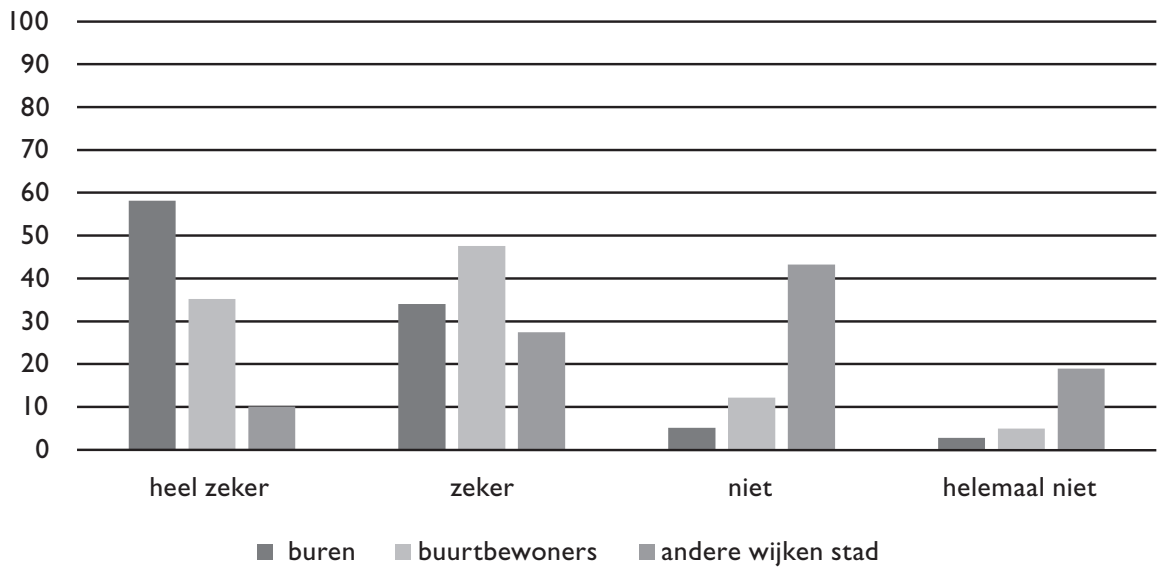

\section{Figuur 2 Bereidheid om hulp te bieden}

bereikbaar te voet, ...) geen beroep kunnen doen op eerstelijnshulp (familie, vrienden), kan men wel rekenen op de tweede lijn.

\subsection{Tot wie richt de burger zich in geval van stroomuitval?}

Naast het aspect van hulp bieden aan familie, vrienden en buurtbewoners is een belangrijke dimensie van de zelfredzaamheid van de burger het vermogen om informatie of hulp te zoeken ingeval communicatiemiddelen zoals GSM, telefoon en internet niet langer functioneren als gevolg van de stroomuitval.

De resultaten zijn niet eenduidig. De burger lijkt allerminst te zijn voorbereid op het inwinnen van hulp of informatie, in de zin dat de antwoorden van de respondenten een heel gespreid patroon vertonen. Politie (14,5\%), centraal plein of station $(11,0 \%)$, gemeentehuis $(9,9 \%)$, buurthuis, ontmoetingscentrum (buurtontmoetingscentrum, buurtwinkel, club, café,...) (9,7\%) blijken belangrijke ontmoetingsplaatsen te zijn voor burgers om informatie en hulp te zoeken. Ziekenhuizen $(7,1 \%)$ en brandweerkazernes $(4,3 \%)$ worden veel minder aangehaald als locatie om hulp te zoeken.

Een belangrijk aandachtspunt is dat een overgroot deel van de respondenten aangeeft dat zij in elk geval (26,8\%) of waarschijnlijk (32\%) geen hulp zullen zoeken en thuis de situatie zullen afwachten. Dit blijkt voornamelijk het geval te zijn voor bejaarden. 70,4\% (38) van de respondenten ouder dan 70 jaar en $64 \%$ (32) van de respondenten tussen 60 en 70 jaar geven aan dat zij thuis blijven wachten op hulp $\left(\chi^{2}(24, N=444)=44,14, p=.001\right)$. Hoewel zij aangeven beter te zijn voorbereid dan jongere gezinnen, speelt het aspect van mobiliteit blijkbaar een belangrijke rol als het gaat om zelf hulp zoeken.

We kunnen hieruit concluderen dat de burger in eerste instantie denkt de situatie onder controle te hebben. Indien hij hulp nodig heeft, zoekt hij dit in zijn eigen 


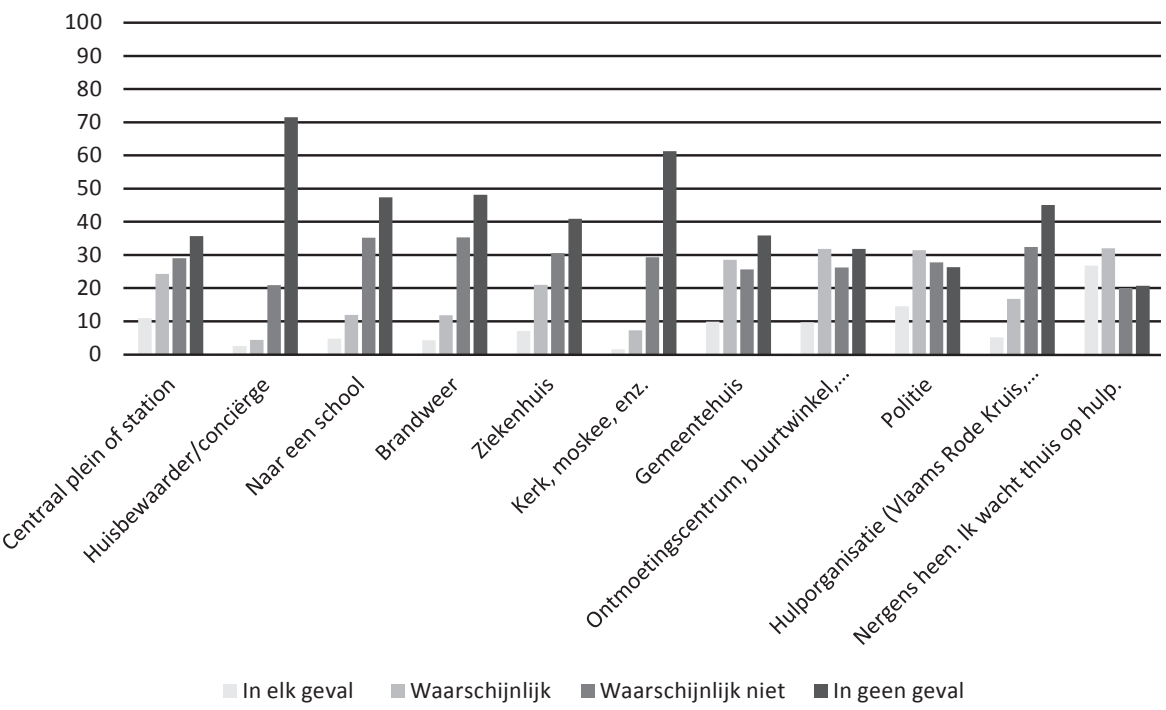

Figuur $3 \quad$ Waar zoekt de burger hulp?

netwerk (familie, vrienden). Een Duitse studie van het Rode Kruis onderschrijft dit. Het merendeel van de Duitse bevolking gelooft dat men zichzelf kan beredderen gedurende een twee weken durende stroomuitval (Emnid 2008, in: Petermann 2011). Verder rekent men op mantelzorg; professionele hulp komt pas op de tweede plaats.

\subsection{Wat verwacht men van de overheid?}

Ook al komt de overheid of professionele hulp slechts op de tweede plaats, toch lijkt het ons interessant om uit te klaren wat de burger nu precies van de overheid verwacht. Uit de bevolkingsbevraging komt duidelijk naar voor dat de burger verwacht dat de overheid inzet op de volgende vier diensten: actuele informatie, verdeling water, medische verzorging en het behandelen van noodoproepen.

$80,3 \%$ van de respondenten (374) vindt het belangrijk dat de overheid inzet op het verdelen van actuele informatie. Hoewel uit onderzoek blijkt dat burgers in grote mate zelfredzaam zijn, zoeken en verwachten burgers in het kader van stroomonderbrekingen wel informatie over de aard en duur van de storing en naar mogelijke handelingsperspectieven. Het voorzien van verzamelpunten met informatie en hulpmiddelen van waaruit de burger zichzelf kan organiseren, wordt in voorgaande studies aangegeven als het meest cruciale (Groenendaal, De Boer \& Neuvel 2010; Petermann 2011). De nood aan informatie blijkt een constante te zijn in vele crisissituaties. Onderzoek naar behoeften van slachtoffers van rampen toont eveneens aan dat slachtoffers nood hebben aan tijdige, correcte en alomvattende informatie over wat er is gebeurd en over wat men nog kan verwachten (De Pauw \& Deprins 2013).

Op de tweede plaats verwacht de burger dat de overheid de verdeling van water garandeert: $73,0 \%$ van de respondenten vindt dit belangrijk (341). Reeds 
bestaand onderzoek duidt vooral op het belang van waterverdeling voor ouderen en personen die zich moeilijk kunnen verplaatsen (Klein, Rosenthal \& Klausner 2005). De resultaten van de voorliggende studie nuanceren deze inzichten. Het zijn voornamelijk oudere respondenten die significant meer zijn voorzien en over voedsel, water en geneesmiddelen beschikken voor een periode die langer duurt dan vijf dagen (zie tabel 7). Op basis van deze empirische informatie zijn vooral jonge gezinnen en gezinnen met peuters het meest kwetsbaar met betrekking tot de waterverdeling.

Op de derde plaats verwacht de burger dat de overheid dringende medische hulpverlening blijft garanderen.

Verder ziet de burger een rol voor de overheid wat de communicatie betreft. Naast de gekende problematiek van het uitvallen van mobiele en vaste telefonie zal de overheid hiervoor moeten anticiperen op een aantal belangrijke problemen die zich voordoen tijdens een stroomuitval. $60,7 \%$ van de respondenten vindt het belangrijk dat 'iemand' kan worden gecontacteerd in geval van nood. Naast de technische problemen van het uitvallen van communicatiemiddelen bieden andere onderzoeken het inzicht aan dat de kwaliteit van de informatie een belangrijke impact zal hebben op de wijze waarop burgers reageren. Personen die zich niet bewust zijn van wat er is gebeurd of hoe incidenten evolueren, zullen sneller gevoelens van hulpeloosheid, desoriëntatie en agressie vertonen (Ohder \& Sticher 2013).

Een belangrijke vaststelling is dat het vertrouwen van de burger in de overheid geen enkele invloed heeft op de verwachting die de burger heeft van de overheid. De Spearman's rho-test duidt erop dat er geen statistisch significant verband bestaat tussen het vertrouwen van de burger in de overheid en welke dienstverlening hij verwacht $(r s[451]=.227, p<.001) .^{3}$

\section{Conclusie en discussie}

De resultaten van deze studie leveren interessante inzichten in hoe de burger zich organiseert bij een mogelijke crisis. Het ontkracht een aantal mythes die ook al door andere studies werden tenietgedaan. Op basis van voorliggend onderzoek is er geen reden om aan te nemen dat de burger zal panikeren, revolteert of gaat plunderen. Integendeel, de burger gaat zich zelfs vrij goed organiseren.

Het antwoord op de eerste onderzoeksvraag, 'Is de burger voorbereid?', kan dan ook in zekere mate positief worden beantwoord. Belangrijk hierbij is dat deze studie tevens het belang van de drie percepties door Terpstra (2010) geformuleerd, onderschrijft.

3 Voor de schaalscore 'vertrouwen in de overheid' werden de antwoorden (1: helemaal geen vertrouwen - 9 heel veel vertrouwen) op de stellingen 'De federale overheid', 'De Vlaamse overheid', 'De lokale overheid', 'De federale politie', 'De lokale politie', 'De inlichtingendiensten (bijv. staatsveiligheid)' opgeteld. Een hoge schaalscore impliceert een heel sterk vertrouwen in de overheid, een lage schaalscore impliceert heel weinig vertrouwen in de overheid. Deze schaal is intern consistent: Cronbach's Alpha $=.871$. 


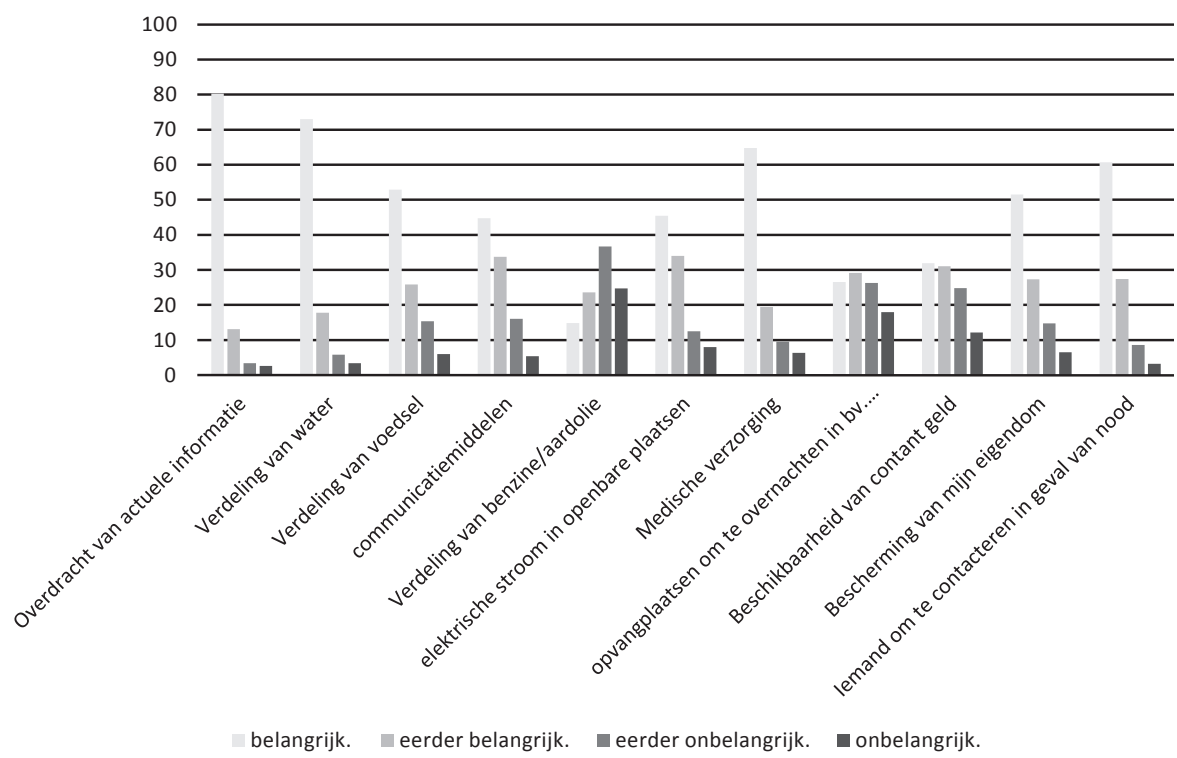

Figuur $4 \quad$ Welke dienstverlening verwacht de burger van de overheid?

Kijken we naar de perceptie van het risico, dan zien we dat de burger over een draagvlak beschikt dat kan worden aangesproken om zich te organiseren tijdens een langdurige stroomuitval. De meeste respondenten bezitten voldoende rantsoen en drank. Het valt bovendien op dat mensen die over een mindere mobiliteit beschikken en/of afhankelijk zijn van geneesmiddelen beter zijn voorbereid. We kunnen hier voorzichtig stellen dat deze groep zich allicht meer bewust is van het mogelijke risico dat men loopt in vergelijking met andere groepen.

Een belangrijk aandachtspunt betreft de voorzieningen waar burgers over beschikken. Vooral gezinnen met één of meer peuters blijken minder goed voorbereid te zijn dan gezinnen met kinderen, samenwonenden en bejaarden. Gezinnen met peuters bezitten significant minder voeding, drank en medicatie voor meerdere dagen. De meest opvallende verschillen stellen we vast met betrekking tot voldoende voorzieningen in het huishouden voor dringende geneesmiddelen. Iets meer dan de helft van de gezinnen met peuters geeft aan minder dan vijf dagen te voorzien als het op belangrijke geneesmiddelen aankomt. Dit inzicht kan helpen de meest kwetsbare groepen in beeld te brengen.

Verder zien we ook dat de burger er in eerste instantie van overtuigd is dat hij zichzelf kan beredden. Bovendien is er de bereidheid om buren en in mindere mate buurtbewoners hulp te bieden, zoals iemand naar het ziekenhuis brengen, goederen delen en vaardigheden ter beschikking stellen. Dit hangt samen met de perceptie van de eigen verantwoordelijkheid. De burger is zich bewust van zijn eigen kunnen en weet waarvoor hij zelf kan instaan en wat hij van de overheid verwacht. Waar zijn eigen kunnen, of liever de perceptie van het eigen kunnen, stopt, zal men zich op de overheid beroepen. Of waar de perceptie van de mogelijk zelf te nemen maatregelen stopt, richt men zich tot de overheid. Dit brengt ons 
meteen bij de tweede onderzoeksvraag, namelijk: wat verwacht men van de overheid?

De burger verwacht van de overheid tijdige en correcte informatie en watervoorziening om aan zijn basisbehoeften te kunnen voldoen. De burger is met andere woorden overtuigd van de grote en belangrijke rol die de overheid heeft te vervullen tijdens een stroomonderbreking. Dit is een mogelijke verklaring voor de discrepantie die we vaststellen tussen de potentiële risicogroepen op basis van gezinssamenstelling en de voorbereidende maatregelen die worden genomen. Hoe of waar de informatie dient te worden verspreid, wordt niet duidelijk uitgesproken. Het onderzoek toont, met andere woorden, een spanning aan tussen de informatiebehoefte van de burger en de wijze waarop die zou moeten worden verspreid. De dynamiek van de crisissituatie zelf zal moeten uitwijzen hoe dit het beste wordt georganiseerd of hoe men het meeste volk bereikt.

Belangrijk hierbij is ook de vaststelling dat sommige mensen vooral niets zullen doen en zullen wachten op hulp. Ook hier legt men een sterke nadruk op de rol van de overheid. Opvallend is dat 'wachten op' meestal werd aangegeven door de meer hulpbehoevenden. Met andere woorden, zij hebben de perceptie minder zelf verantwoordelijk te zijn, omdat men het vaak niet meer kan, en te rekenen op anderen.

Bovendien blijft de overheid ook de belangrijkste actor voor het verzekeren van dringende hulpverlening. Niet onbelangrijk is het inzicht dat bijna $50 \%$ van de respondenten aangeeft thuis te zullen wachten tot er iemand met informatie bij hen komt of dringende hulp komt bieden (ook indien er geen gebruik kan worden gemaakt van telecommunicatie). Deze 'onbeholpenheid' situeert zich bijna uitsluitend bij de oudere respondenten. Vanaf de leeftijdstijdskaap van 60 jaar wordt gewoon thuis gewacht op hulp.

Deze vaststelling pleit misschien voor het behouden van de klassieke aanpak van 'deur tot deur' hulp aanbieden. Ook al wordt er vaak gepleit voor de inzet van sociale media en andere informatiekanalen, uit deze studie blijkt dat de meest hulpbehoevende doelgroep zal wachten tot de hulp of informatie bij hen geleverd wordt. Met andere woorden, de nieuwe kanalen zijn zeker een mooie aanvulling, maar de 'deur tot deur'-benadering blijft hoe dan ook noodzakelijk.

\section{Literatuur}

Bankhoff, G, G. Frerks \& D.J.M. Hilhorst (eds.) (2004) Mapping vulnerability; Disasters, development and people. London: Earthscan.

De Pauw, E. \& F. Deprins (2013) Nazorg aan slachtoffers van rampen bevraagd. In: Orde van de Dag, thema: Noodhulp (p. 42-51). Kluwer: Deventer.

Dupont, I. \& G. Reniers (2010) Vergelijkende studie tussen veiligheid en beveiliging: Toepassen van proactieve beschermingsprogramma's bij kritieke infrastructuren. HUB RESEARCH PAPER 2010/25.

Helsloot, I. \& B. van 't Padje (2010) Zelfredzaamheid: Concepten, thema's en voorbeelden nader beschouwd. Den Haag: Boom Juridische uitgevers.

Helsloot, I. (2015) De schrale troost van 30 jaar professionalisering. In: E. Devroe, A. Duchatelet, P. Ponsaers, M. Easton, L. Gunter Moor \& L. Wontergem (eds.) Zicht op 
first responders. Handboek bij het beheer van evenement en noodsituaties in Nederland en België (p. 323-350). Reeks Veiligheidsstudies 12, Antwerpen: Maklu.

Hijlkema, S., S. van der Meulen \& M. Moll (2011) Meting zelfredzaamheid en sociale samenhang in de Veiligheidsregio IJsselland. Een casusstudie in Zwolle en Olst-Wijhe. Geraadpleegd op www.windesheim.nl/ /media/Files/Windesheim/Research \%20Publications/DeelrapportageonderzoekZelfredzaamheid12122011definitief.pdf.

Lenz, S. (2009) Vulnerabilität Kritische Infrastrukturen. Bonn: Bundesamt fürBevölkerungsschutz und Katastrophenhilfe.

Neuvel, J.M.M., J. Groendendaal \& D.J. de Boer (2010) Zelfredzaamheid bij de stroomstoring in de Bollenstreek, Saxion Hogeschool.

Muller, E. (2004) Veiligheid: Studies over inhoud, organisatie en maatregelen. Den Haag: Boom Juridische Uitgevers.

Ohder, C. \& B. Sticher (2013) Approaches towards a community-oriented and enabling disaster management model. In: Chr. Unger, Th. Mitschke \& D. Freudenberg (eds.), Crisis management - Emergency planning - Civil Protection. Festschrift on the occasion of 60 years training in civil protection offered by partners, friends and employees of the Federal Office of Civil Protection and Disaster Assistance.

Petermann, T., H. Bradke, A. Lüllmann, M. Poetzsch \& U. Riehm (2011) What happens during a blackout. Consequences of a prolonged and wide-ranging power outage. Report for the Committee on Education, Research and Technology Assessment, 265 p.

Ruitenberg, A.G.W. \& I. Helsloot (2004) Zelfredzaamheid van burgers bij rampen en zware ongevallen. Alphen aan den Rijn: Kluwer.

Scholters, A. \& I. Helsloot (2007) Stroomuitval in de Bommeler-en Tielerwaard in december 2007. Arnhem: Drukkerij Roos \& Roos.

Schweer, B., C. Ohder, B. Sticher e.a. (2014) Katastrophenschutz im Umbruch - Ansätze der Bürgeraktivierung und -einbeziehung im internationalen Vergleich - Bericht zum Forschungsprojekt 'Katastrophenschutz-Leuchttürme als Anlaufstelle für die Bevölkerung in Krisensituationen' (Kat-Leuchttürme).

Terpstra, T. (2010) Flood preparedness: thoughts, feelings and intentions of the dutch public. Psychologie van Conflict, Risico \& Veiligheid (PCRVU). Universiteit Twente.

Van Steen, P. (2015) Ziekenhuis zonder noodstroom. Skipr, 8(3), 45-45.

Wijnja, K. (2014) Klopt jouw hart voor burgerhulpverlening? Een kwalitatief onderzoek naar de relatie tussen zelfredzaamheid en actief burgerschap bij het besluit van burgers om zich aan te melden voor HartslagNu (masterscriptie Utrecht). 


\section{Bijlage 1: Steekproeftrekking}

Tabel 1 Achtergrondkenmerken steekproef

\begin{tabular}{ll}
\hline Steekproef naar achtergrondkenmerken & Procent (absoluut aantal) \\
\hline Geslacht & $48,9(23 \mathrm{I})$ \\
Man & $50,8(240)$ \\
Vrouw & \\
Stad & $70,3(329)$ \\
Gent & $29,7(139)$ \\
Kortrijk & \\
Leeftijd & $27,5(130)$ \\
I9-30 jaar & $16,1(76)$ \\
3 I-40 jaar & $15,9(75)$ \\
4 I-50 jaar & $16,9(80)$ \\
5 I-60 jaar & $11,4(54)$ \\
$6 I-70$ jaar & $11,9(56)$ \\
ouder dan 70 jaar & \\
Immigratieachtergrond & $89,6(424)$ \\
Beide ouders van Belgische afkomst & $4,7(22)$ \\
Eén ouder niet Belgische afkomst & $5,7(27)$ \\
Beide ouders niet Belgische afkomst & \\
Tewerkstelling & $43,9(207)$ \\
Werkt voltijds & $11,7(55)$ \\
Werkt parttime & $19,7(93)$ \\
Student & $17,6(83)$ \\
Pensioen & $3,6(17)$ \\
Tijdelijk werkloos & $2,1(10)$ \\
Huisvrouw/huisman & $1,4(6)$ \\
Andere &
\end{tabular}

Tabel 2 Gezinssamenstelling steekproef

\section{Gezinssamenstelling naar achtergrond- Procent (absoluut aantal)} kenmerken

\section{Gezinsstructuur}

Woont alleen

Woont samen

$64,9(307)$

Woont samen met schoolgaande kinderen

Woont samen met peuter

$12,5(59)$

Woont samen met huisdier 
Tabel 2 (Vervolg)

\section{Gezinssamenstelling naar achtergrond- Procent (absoluut aantal)} kenmerken

\begin{tabular}{ll}
\hline Aantal inwoners per gezin & $21,0(99)$ \\
\hline & $31,4(148)$ \\
3 & $18,0(85)$ \\
4 & $18,3(86)$ \\
5 & $7,0(33)$ \\
6 & $2,1(10)$ \\
7 & $1,3(6)$ \\
8 & $0,4(2)$ \\
I4 & $0,2(1)$ \\
25 & $0,2(1)$ \\
Is afhankelijk van: & \\
Geneesmiddelen & $28,5(135)$ \\
Minstens één keer per week medische zorgen & $7,8(37)$ \\
Medische apparaten & $2,7(13)$ \\
Beperkte mobiliteit & $6,6(31)$ \\
Heeft een andere beperking & $4,0(19)$ \\
Woont samen met persoon die afhanke- & \\
lijk is van: & $19,5(91)$ \\
Geneesmiddelen & $5,8(27)$ \\
Minstens één keer per week medische zorgen & $2,8(13)$ \\
Medische apparaten & $4,5(21)$ \\
Beperkte mobiliteit & $8,2(39)$ \\
Heeft een andere beperking & \\
\hline
\end{tabular}


Bijlage 2: Analyses

Tabel 3 Voorziening gezin met en zonder kinderen

\begin{tabular}{lll}
\hline & $\begin{array}{l}\text { Kinderen Procent (absoluut } \\
\text { aantal) }\end{array}$ & $\begin{array}{l}\text { Geen kinderen Procent } \\
\text { (absoluut aantal) }\end{array}$ \\
\hline Voeding* & $24,3(36)$ & $26,0(83)$ \\
I-2 dagen & $38,5(57)$ & $43,3(138)$ \\
3-4 dagen & $12,8(19)$ & $17,2(55)$ \\
5-6 dagen & $24,3(36)$ & $13,5(43)$ \\
> 6 dagen & & \\
Drank & $3,4(5)$ & $6,6(21)$ \\
I-2 dagen & $15,4(23)$ & $15,1(48)$ \\
3-4 dagen & $22,1(33)$ & $26,8(85)$ \\
5-6 dagen & $59,1(88)$ & $51,4(163)$ \\
> 6 dagen & & \\
Geneesmiddelen & $5,8(7)$ & $6,9(16)$ \\
I-2 dagen & $8,3(10)$ & $8,2(19)$ \\
3-4 dagen & $7,5(9)$ & $6,9(16)$ \\
5-6 dagen & $78,3(94)$ & $78,1(182)$ \\
> 6 dagen & &
\end{tabular}

Chi-kwadraat en Cramer's V: $\left(^{*}\right)$ de verschillen tussen gezin met en gezin zonder kinderen zijn statistisch significant op het niveau: $p<0.05^{*}=p<0.01 * *=p<0.00 I^{* * *}$

Tabel $4 \quad$ Voorziening gezin met en zonder peuter

\begin{tabular}{lll}
\hline & $\begin{array}{l}\text { Peuter Procent (absoluut } \\
\text { aantal) }\end{array}$ & $\begin{array}{l}\text { Geen peuter Procent } \\
\text { (absoluut aantal) }\end{array}$ \\
\hline Voeding & & \\
I-2 dagen & $27, I(16)$ & $25,2(103)$ \\
3-4 dagen & $40,7(24)$ & $41,9(17 I)$ \\
5-6 dagen & $11,9(7)$ & $16,4(67)$ \\
> 6 dagen & $20,3(12)$ & $16,4(67)$ \\
Drank & & \\
I-2 dagen & $6,8(4)$ & $5,4(22)$ \\
3-4 dagen & $15,3(9)$ & $15,2(62)$ \\
5-6 dagen & $22,0(13)$ & $25,8(105)$ \\
$>$ 6 dagen & $55,9(33)$ & $53,6(2 \mid 8)$ \\
Geneesmiddelen**** & & \\
I-2 dagen & $6,7(3)$ & $6,5(20)$ \\
3-4 dagen & $24,4(I I)$ & $5,8(I 8)$
\end{tabular}


Tabel 4 (Vervolg)

\begin{tabular}{lll}
\hline & $\begin{array}{l}\text { Peuter Procent (absoluut } \\
\text { aantal) }\end{array}$ & $\begin{array}{l}\text { Geen peuter Procent } \\
\text { (absoluut aantal) }\end{array}$ \\
\hline 5-6 dagen & $8,9(4)$ & $6,8(2 \mathrm{I})$ \\
>6 dagen & $60,0(27)$ & $80,8(249)$ \\
\hline
\end{tabular}

Chi-kwadraat en Cramer's V: $\left(^{*}\right)$ de verschillen tussen gezin met kinderen en gezin zonder kinderen zijn statistisch significant op het niveau: $p<0.05^{*}=p<0.01 * *=p<0.001 * * *$

Tabel $5 \quad$ Alleenstaanden en samenwonenden

\begin{tabular}{lll}
\hline & $\begin{array}{l}\text { Samenwonend Procent } \\
\text { (absoluut aantal) }\end{array}$ & $\begin{array}{l}\text { Alleenstaand Procent } \\
\text { (absoluut aantal) }\end{array}$ \\
\hline Voeding & $25,0(76)$ & $24,4(43)$ \\
I-2 dagen & $42,8(130)$ & $39,9(27)$ \\
3-4 dagen & $15,5(47)$ & $16,6(27)$ \\
5-6 dagen & $16,8(51)$ & $17,2(28)$ \\
> 6 dagen & & \\
Drank & $7,0(21)$ & $3,0(5)$ \\
I-2 dagen & $14,6(44)$ & $16,4(27)$ \\
3-4 dagen & $25,2(76)$ & $25,5(42)$ \\
5-6 dagen & $53,2(160)$ & $55,2(91)$ \\
> 6 dagen & & \\
Geneesmiddelen & $6,3(14)$ & $6,9(9)$ \\
I-2 dagen & $8,6(19)$ & $7,6(10)$ \\
3-4 dagen & $7,2(16)$ & $6,9(9)$ \\
5-6 dagen & $77,9(173)$ & $78,6(103)$ \\
> 6 dagen & &
\end{tabular}

Chi-kwadraat en Cramer's V: $(*)$ de verschillen tussen gezin met kinderen en gezin zonder kinderen is statistisch significant op het niveau: $p<0.05^{*}=p<0.01 * *=p<0.00 I^{* * *}$

Tabel $6 \quad$ Voorziening leeftijd gezinsleden

\begin{tabular}{|c|c|c|c|c|c|c|}
\hline & $\begin{array}{l}19-30 \mathrm{jr} \\
\text { Procent } \\
\text { (absoluut } \\
\text { aantal) }\end{array}$ & $\begin{array}{l}3 \mathrm{I}-40 \mathrm{jr} \\
\text { Procent } \\
\text { (absoluut } \\
\text { aantal) }\end{array}$ & $\begin{array}{l}4 \mathrm{I}-50 \mathrm{jr} \\
\text { Procent } \\
\text { (absoluut } \\
\text { aantal) }\end{array}$ & $\begin{array}{l}5 \mathrm{I}-60 \mathrm{jr} \\
\text { Procent } \\
\text { (absoluut } \\
\text { aantal) }\end{array}$ & $\begin{array}{l}\text { 6I-70 jr } \\
\text { Procent } \\
\text { (absoluut } \\
\text { aantal) }\end{array}$ & $\begin{array}{l}>70 \\
\text { Pro- } \\
\text { cent } \\
\text { (abso- } \\
\text { luut } \\
\text { aantal) }\end{array}$ \\
\hline \multicolumn{7}{|l|}{ Voeding* } \\
\hline I-2 dagen & $26,935)$ & $40,0(30)$ & I8,9(14) & $16,3(13)$ & $27,8(15)$ & $\begin{array}{l}22,6 \\
(12)\end{array}$ \\
\hline 3-4 dagen & $46,2(60)$ & $38,7(29)$ & $39,2(29)$ & 40,0 (32) & $38,9(2 I)$ & $\begin{array}{l}45,3 \\
(24)\end{array}$ \\
\hline $5-6$ dagen & I5,4 (20) & $13,3(10)$ & $17,6(13)$ & $20,0(16)$ & $I I, I(6)$ & I5,I (8) \\
\hline$>6$ dagen & II,5 (I5) & $8,0(6)$ & $24,3(18)$ & $23,8(19)$ & $22,2(12)$ & $17,0(9)$ \\
\hline
\end{tabular}


Tabel $6 \quad$ (Vervolg)

\begin{tabular}{|c|c|c|c|c|c|c|}
\hline & $\begin{array}{l}19-30 \text { jr } \\
\text { Procent } \\
\text { (absoluut } \\
\text { aantal) }\end{array}$ & $\begin{array}{l}3 \mathrm{I}-40 \text { jr } \\
\text { Procent } \\
\text { (absoluut } \\
\text { aantal) }\end{array}$ & $\begin{array}{l}4 \mathrm{I}-50 \mathrm{jr} \\
\text { Procent } \\
\text { (absoluut } \\
\text { aantal) }\end{array}$ & $\begin{array}{l}5 \mathrm{I}-60 \mathrm{jr} \\
\text { Procent } \\
\text { (absoluut } \\
\text { aantal) }\end{array}$ & $\begin{array}{l}\text { 6I-70 jr } \\
\text { Procent } \\
\text { (absoluut } \\
\text { aantal) }\end{array}$ & $\begin{array}{l}>70 \\
\text { Pro- } \\
\text { cent } \\
\text { (abso- } \\
\text { luut } \\
\text { aantal) }\end{array}$ \\
\hline \multicolumn{7}{|l|}{ Drank** } \\
\hline I-2 dagen & $7,8(10)$ & I4,5 (II) & $\mathrm{I}, 3(\mathrm{I})$ & $2,5(2)$ & $3,8(2)$ & $0(0)$ \\
\hline 3-4 dagen & $19,4(25)$ & $18,4(14)$ & $16,0(12)$ & $10,0(8)$ & I5,4 (8) & $7,5(4)$ \\
\hline 5-6 dagen & 27,1 (35) & $19,7(15)$ & $18,7(14)$ & $32,5(26)$ & $23, I(12)$ & $\begin{array}{l}28,3 \\
(15)\end{array}$ \\
\hline > 6 dagen & 45,7 (59) & $47,4(36)$ & $64,0(48)$ & $55,0(44)$ & $57,7(30)$ & $\begin{array}{l}64,2 \\
(34)\end{array}$ \\
\hline \multicolumn{7}{|c|}{$\begin{array}{l}\text { Genees- } \\
\text { middelen** }\end{array}$} \\
\hline I-2 dagen & $8,6(7)$ & I2,7 (7) & $4,0(2)$ & $6,2(4)$ & $4,3(2)$ & $1,9(1)$ \\
\hline 3-4 dagen & $12,3(10)$ & $18,2(10)$ & $0(0)$ & $3, I(2)$ & $8,5(4)$ & $3,8(2)$ \\
\hline 5-6 dagen & $3,7(3)$ & $9,1(5)$ & $8,0(4)$ & I3,8 (9) & $0(0)$ & $7,5(4)$ \\
\hline > 6 dagen & $75,3(6 \mathrm{I})$ & $60,0(33)$ & $88,0(44)$ & $76,9(50)$ & $87,2(4 I)$ & $\begin{array}{l}86,8 \\
(46)\end{array}$ \\
\hline
\end{tabular}

Chi-kwadraat en Cramer's V: $(*)$ de verschillen tussen gezin met kinderen en gezin zonder kinderen zijn statistisch significant op het niveau: $p<0.05^{*}=p<0.01 * *=p<0.001 * * *$

Tabel 7 Voorziening persoon afhankelijk medische geneesmiddelen

Ja Procent (absoluut aantal) Neen Procent (absoluut aantal)

\begin{tabular}{lll}
\hline Voeding & & \\
I-2 dagen & $27, I(36)$ & $5,0(83)$ \\
3-4 dagen & $45, I(60)$ & $40,2(134)$ \\
5-6 dagen & $12,0(16)$ & $17,4(58)$ \\
> 6 dagen & $15,8(2 I)$ & $17,4(58)$ \\
Drank & & \\
I-2 dagen & $6,0(8)$ & $5,4(18)$ \\
3-4 dagen & $10,4(14)$ & $17,2(57)$ \\
5-6 dagen & $27,6(37)$ & $24,4(8 I)$ \\
$>$ > dagen & $56,0(75)$ & $53,0(176)$ \\
Geneesmiddelen* & & \\
I-2 dagen & $2,3(3)$ & $9,0(20)$ \\
3-4 dagen & $5,3(7)$ & $9,9(22)$ \\
5-6 dagen & $6,0(8)$ & $7,6(17)$ \\
$>6$ dagen & $85,7(I 14)$ & $72,6(162)$ \\
\hline
\end{tabular}

Chi-kwadraat en Cramer's V: $(*)$ de verschillen tussen gezin met kinderen en gezin zonder kinderen zijn statistisch significant op het niveau: $p<0.05^{*}=p<0.01 * *=p<0.00 I^{* * *}$ 
Tabel 8 Voorziening persoon afhankelijk medische zorg

Ja Procent (absoluut aantal) Neen Procent (absoluut aantal)

\section{Voeding}

I-2 dagen

24,9 (107)

3-4 dagen

40,5 (I5)

$41,9(180)$

5-6 dagen

$16,0(69)$

$>6$ dagen

16,0 (74)

\section{Drank}

I-2 dagen

3-4 dagen

5-6 dagen

$>6$ dagen

\section{Geneesmiddelen*}

$\begin{array}{lll}\text { I-2 dagen } & 2,2(1) & 6,5(2 I) \\ 3-4 \text { dagen } & 17,6(7) & 7, I(23) \\ 5-6 \text { dagen } & 17,6(9) & 5,9(19) \\ >6 \text { dagen } & 58,8(20) & 79,5(256)\end{array}$

Chi-kwadraat en Cramer's V: $(*)$ de verschillen tussen gezin met kinderen en gezin zonder kinderen zijn statistisch significant op het niveau: $p<0.05^{*}=p<0.0$ I** $=p<0.00 I^{* * * *}$

Tabel $9 \quad$ Voorziening persoon beperkte mobiliteit

\begin{tabular}{lll}
\hline & Ja Procent (absoluut aantal) & $\begin{array}{l}\text { Neen Procent (absoluut } \\
\text { aantal) }\end{array}$ \\
\hline Voeding & $29,0(9)$ & $25,2(110)$ \\
I-2 dagen & $32,3(10)$ & $42,4(185)$ \\
3-4 dagen & $9,7(3)$ & $16,3(7 I)$ \\
5-6 dagen & $29,0(9)$ & $16,1(70)$ \\
> 6 dagen & & \\
Drank & $3,2(1)$ & $5,7(25)$ \\
I-2 dagen & $9,7(3)$ & $15,6(68)$ \\
3-4 dagen & $12,9(4)$ & $26,2(114)$ \\
5-6 dagen & $74,2(23)$ & $52,4(228)$ \\
> 6 dagen & & \\
Geneesmiddelen* & $3,4(1)$ & $6,7(22)$ \\
I-2 dagen & $13,8(4)$ & $7,6(25)$ \\
3-4 dagen & $20,7(6)$ & $5,8(19)$ \\
5-6 dagen & $62, I(18)$ & $78,9(258)$ \\
> 6 dagen & &
\end{tabular}

Chi-kwadraat en Cramer's V: $(*)$ de verschillen tussen gezin met kinderen en gezin zonder kinderen zijn statistisch significant op het niveau: $p<0.05 *=p<0.01 * *=p<0.001 * * *$ 